\title{
PLURALISM AND LEGAL PHILOSOPHY
}

\author{
Margaret Davies, Flinders University, Adelaide
}

\section{Two (Positivist) Dogmas of Legal Monism ${ }^{1}$}

Legal pluralism celebrates the diversity of human organisations and (for some) emphasises the non-systematic, disorderly, nature of our normative relationships. It offers a vision of legal phenomena in counterpoint to the statist insistence on system, institutions, and coherence. In recent pluralist scholarship, there has been a general call for legal pluralism to be true to itself by becoming more pluralistic. ${ }^{2}$ The observation has been rightly made that pluralism which is too wedded to the objective facts of social arenas or an essentialist concept of law, will ultimately reinscribe the singularity of a conceptual system in some form. A pluralist pluralism must therefore call into question one or preferably both of the central monistic dogmas of positivist sociology of law and positivist legal philosophy - that is, the dogma of the singularity of the social field of which law is a part, and the dogma of the singularity of the concept of law.

In this paper I ask what such a pluralist pluralism has to do with legal theory (understood as the theory of positive state-based law) ${ }^{3}$ and argue that it is possible to see state law as both singular and plural. Most importantly, a pluralist approach to law is not in my view a theoretical end in itself but rather a means of disrupting the hegemonic forms of power enshrined in conventional state-based definitions of law. In this sense, using the language of pluralism to narrate a new understanding of state law will hopefully help to remedy its seemingly chronic deafness to the normative contexts of those symbolically or legally positioned as other to law.

1 With apologies to Quine, "Two Dogmas of Empiricism" (1951) 60 Phil.Rev. 20; whose 'two dogmas' are the dogma of the analytic-synthetic distinction in philosophy, and the dogma of reductionism - the notion that a meaning can be reduced to a factual state. The reference to Quine is not inconsequential, as his critique of these dogmas can be read as leading to interpretive and conceptual pluralism. Although Quine did not follow this path himself, preferring to reinforce a scientific behaviourism, to some his ideas indicated the cultural and conventional basis of all knowledge. I wish to thank Davina Cooper, Martha-Marie Kleinhans, Ngaire Naffine, Jeremy Webber and the referees for their comments on this article in its various forms.

2 See in particular Manderson, "Beyond the Provincial: Space, Aesthetics, and Modernist Legal Theory" (1996) 20 MULR 1048; Kleinhans and Macdonald, "What is a Critical Legal Pluralism?" (1997) 12(2) Can.J.L. \& Soc'y 25; Tamanaha, A General Jurisprudence of Law and Society (2001); Eberhard, "Towards an Intercultural Legal Theory: The Dialogical Challenge" (2001) 10(2) Soc. \& L.S. 171; Melissaris, "The More the Merrier? A New Take on Legal Pluralism" (2004) 13(1) Soc \& L.S. 57.

3 Legal theory is sometimes understood as the theory of law in a global or even universal sense, asking 'what is law?' rather than 'what is law in Western liberal democracies?' It seems fairly clear that the second question rather than the first forms the real basis for most legal theory; therefore the legal theory I refer to has its cultural location in Western legalities. 
Legal pluralism is traditionally understood to relate to a multiplicity of normative systems which coexist in a defined social or geopolitical domain. For instance, it has become commonplace to speak of legal pluralism in colonial and postcolonial societies, where the imposition of colonial law has not completely effaced or absorbed a pre-existing legal order. Two (or more) legal orders, each with at least some degree of independence from the other, exist in the one geographical area. In socio-legal scholarship, interconnected regulatory and normative structures in all spheres of social ordering are also increasingly referred to in the language of legal pluralism. ${ }^{4}$ The legal pluralist approach has been effective in decentring state law and state power in the socio-legal analysis of how people and societies order their existences. It has also critiqued the notion, promulgated by a number of influential legal theorists, that the characteristics of 'law' and 'legal system' are typified by the positive law of nation states.

With the exception of a few contributions mainly published since the late 1990s, legal pluralist thought has focused on the understanding of the objective facts of legal order in society. It has taken little theoretical notice of the alternative readings of socio-legal spaces which play out in relation to multifaceted power relations. ${ }^{5}$ As Desmond Manderson comments, "Legal pluralism multiplies legal systems, but it does not doubt their objective and defined content." In its orthodox manifestation, legal pluralism positively identifies, describes and theorises the multiple normative relationships within a social terrain. In an influential article published in 1986, John Griffiths said that

“Any sort of 'pluralism' necessarily implies that more than one of the sort of thing concerned is present within the field described. In the case of legal pluralism, more than one 'law' must be present"

Thus, he says, legal pluralism "is an attribute of a social field and not of law."7 According to this fairly uncontroversial view, legal pluralism is something which can be observed and theorised in the socio-legal field. It is not a characteristic of law and nor is it a characteristic of the interpretability of the social. Pluralism is objectively attributed to the geo-political space in which law finds itself. Whatever definition of 'law' is adopted, the term 'legal pluralism' identifies and names the co-existence of legal orders in a defined space.

As Brian Tamanaha points out, legal pluralism has generally relied upon some theoretical account of what law is, and then studied a plurality of such 'laws' in a particular geographical or social landscape. One perceived problem with this approach has been the inability of legal pluralists to settle on a definition of law and the resulting difficulty that properly legal as opposed to merely social normative orders become poorly defined. Anxiety over expanding the concept of law into what might be regarded as legally

${ }^{4}$ For an overview of these two forms of legal pluralism see Engle Merry, "Legal Pluralism" (1988) 22(5) L. \& Soc.Rev. 869.

5 Cooper, Challenging Diversity: Rethinking Equality and the Value of Difference (2004).

6 Manderson, supra n.2, at 1060.

7 Griffiths, "What is Legal Pluralism?" (1986) 24 J Legal Plur 1. 
trivial spheres of normativity mirrors the legal philosophical desire for a bounded concept of law. (I think we could question whether these issues are as problematic as some insist, but that is not the purpose of this paper.) As an antidote, Tamanaha proposes what he terms a 'non-essentialist' legal pluralism, which recognises that law does not necessarily have an essence. As he explains it;

"I assume that the label 'law' is applied to what are often quite different phenomena - sometimes involving institutions or systems, sometimes not; sometimes connected to concrete patterns of behaviour, sometimes not; sometimes using force, sometimes not. Thus, the plurality I refer to involves different phenomena going by the label 'law', whereas legal pluralism as typically conceived involves a multiplicity of one basic phenomenon, 'law' (as defined)" 8

The departure from standard pluralist thought represented by Tamanaha's approach is that he does not insist upon a universally-accepted definition of law. Instead, "Law is whatever people identify and treat through their social practices as 'law' (or recht, or droit, etc.)." There can be a plurality of concepts of law, as well as (one would presume) plural manifestations of a single concept of law. However, Tamanaha maintains the position that pluralism is "an attribute of a social field." In other words, for Tamanaha, the pluralist enterprise remains essentially positivist and empirical - the description and theorisation of normative 'objects' in society. He says, for instance, that a "state of 'legal pluralism' . . . exists whenever more than one kind of 'law' is recognized through the social practices of a group in a given social arena." Tamanaha's method, while representing a significant departure from the assumption that the concept of law has a positive essence, reinscribes the orthodox pluralist focus upon a limited (categorically defined) and objectively present law. Moreover, although the statist focus of orthodox legal positivism is rejected by Tamanaha's socio-legal positivism, the separability of law from non-law is reinforced, ${ }^{9}$ perhaps underlining a view of the singularity of the legal field.

\section{Socio-Legal and Philosophical Approaches to Law}

Later in this article I want to consider the nature of a pluralist pluralism in more detail. First, however, I want to summarise the points of resistance in mainstream legal theory to pluralist thought. It is not self-evident that an approach which has so much to say about the relationship between law and state should be so comprehensively foreclosed by a discipline which aims to understand the nature of law. Other sceptical approaches such as legal realism, feminist legal scholarship, critical legal studies, and postmodernism, have found a voice in theoretical accounts of law - even conventional positivist scholarship acknowledges the existence of these critical approaches to law, and increasingly enters into dialogue with the non-positivist

8 Tamanaha, supra n.2, at 194.

9 See also Einar Himma, "Do Philosophy and Sociology Mix? A Non-Essentialist Socio-Legal Positivist Analysis of the Concept of Law" (2004) 24(4) OJLS 717 at 717. 
approaches. Just why is it then that pluralist thought has made so little impact upon understanding the concept of law?

There are several rather obvious ways of answering this question which can be quickly sketched. At the level of discipline, legal pluralism has been situated within anthropological, ethnographic, and sociological scholarship on law. Its lack of influence in legal philosophy is first and foremost related to the intellectual history of disciplinary separation of empirical social-based disciplines from the speculative discipline of philosophy. ${ }^{10}$ Such divisions have been reinforced in both the analytical and conceptual schools of positivist legal philosophy: against the likes of Eugen Ehrlich's social-based approach to law or Von Savigny's historicism, Hans Kelsen for instance insisted upon the difference between the 'natural' or behaviouristic interpretation of "sensible, temporo-spatial events" and their legal significance. ${ }^{11}$ His pure philosophical approach to law concerned the immanent meanings of legally-significant events, while sociology of law was concerned with an external and factual account of law. In contrast to continental European legal theory, which has emphasised conceptual systembuilding, legal philosophy in the Anglo-sphere has generally had a more empirical focus on law as a social construction. This does not mean that law is seen to be fully embedded in the social, rather that, although originally derived from social sources, it achieves a separate institutional life of its own. Thus, the legal philosophical project of presenting law from the inside or according to lawyers has been largely continued in the analytical tradition, despite Hart's (unconvincing) claim in The Concept of Law to have written 'an essay in descriptive sociology'. ${ }^{12}$

In recent decades, it is true that both liberal and critical legal thought have strongly challenged the conceptual coherence of the inside/outside distinction in legal thought ${ }^{13}$ feminist and critical race theory have seen the distinction (with its associated language of legal reason and objectivity) as a means by which legal culture masks its participation in hegemonic forms of power, while poststructural analysis has regarded it as a deconstructible

10 On the division of socio-legal studies from legal theory see Tamanaha, supra n.2, at 134; Norrie, "From Critical to Socio-Legal Studies: Three Dialectics in Search of a Subject" (2000) 9 Soc. \& L.S. 85; Lacey, "Normative Reconstruction in Socio-Legal Theory," in Lacey (ed.), Unspeakable Subjects: Feminist Essays in Legal and Social Theory (1998); see also Cotterrell, "Subverting Orthodoxy, Making Law Central: A View of Sociolegal Studies” (2002) 29 J.L. \& Soc'y. 632 at 634-638. Jiŕí Př́ibán emphasizes the continuities, especially between prepostmodern critical legal studies and sociology of law in "Sharing the Paradigms? Critical Legal Studies and the Sociology of Law," in Banakar and Travers (eds.), An Introduction to Law and Social Theory (2002).

11 See Kelsen, "The Pure Theory of Law" (1934) 20 LQR 474 at 479-480. Kelsen's comments were directed at those legal theorists, such as Eugen Ehrlich, who did not sharply distinguish between the social and legal spheres.

12 Hart, The Concept of Law ( $2^{\text {nd }}$ ed, 1996), p.v. As Roger Cotterrell notes 'there is a kind of sociological drift (but no serious sociology) in Hart's normative legal theory'; Cotterrell, The Politics of Jurisprudence: A Critical Introduction to Legal Philosophy (1989), p.96.

13 In terms of the liberal challenge to law's closure, see Dworkin, Law's Empire (1986). 
consequence of discursive violence. ${ }^{14}$ It is now commonplace to observe that the alleged institutional and conceptual separation of law from cultural, political and social processes is one of law's foundational fictions: law is not only a product of socio-political discourse as enshrined for instance in political institutions, law is fully embedded in, and in fact inseparable from, the socio-political field. However, this does not mean that critical legal thought has facilitated a practical coming together of legal theory and sociolegal thought. As Alan Norrie has argued the focus of much critical legal thought (especially that which takes place under the influence of Derrida's 'Force of Law') is, like traditional legal theory, upon an immanent rather than a socio-political critique. There are some instances, of course, where a socio-legal and a philosophical critique of law have been usefully merged: one of the most consistent areas is feminist legal theory where the analysis of the concept and nature of law has been combined with a critique of power in a socio-political context. ${ }^{15}$

At the same time, Nicola Lacey comments that the 'quasi-scientific stance' of some socio-legal scholarship and its failure "to take a sophisticated approach to the complexity of interactions between legal and extra-legal practices," provide critical legal theory with a reason for disregarding it as "theoretically and politically naïve."16 Certainly much legal pluralist scholarship, in analysing pluralism as an objective fact about the socio-legal world, has not proven especially useful to postmodern theorists with their emphasis upon reflexivity or to feminist legal scholars with their emphasis upon the channelling of power through the dominant legal system. ${ }^{17}$ The coming together of the terminology of postmodernism and pluralism is perhaps best epitomised by the work of Boaventura de Sousa Santos. ${ }^{18}$ Santos characterises his work as postmodernist, but Eve Darian-Smith has critiqued this characterisation, saying that Santos "cannot think beyond the autonomous liberal subject that in effect locks him into a modernist frame."19

14 Derrida, "Force of Law: The "Mystical Foundation of Authority" (1990) 11 Cardozo L.Rev. 919; also published in Cornell et al. (eds.), Deconstruction and the Possibility of Justice (1992). Associated literature includes Rosenfeld, "Derrida, Law, Violence and the Paradox of Justice" (1991) 13 Cardozo L.R. 1267; Davies, Delimiting the Law: 'Postmodernism' and the Politics of Law (1996); Wolcher "The Man in the Room: Remarks on Derrida's Force of Law" (1996) 7 Law \& Crit. 35; and, Davies, "Derrida and Law: Legitimate Fictions," in Cohen (ed.), Jacques Derrida and the Humanities (2001) [hereinafter Davies, Derrida and Law].

15 See for instance, Lacey, Unspeakable Subjects (1998).

16 Lacey, supra n.10, at 231.

17 There is a great deal of anthropological work on gender and pluralism in postcolonial societies, but little on the implications of pluralism for a feminist analysis of Western law. Having said that, of course, a growing body of scholarship considers issues of cultural and religious diversity as it intersects with gender in the context of law, but rarely using the terminology or paradigms of legal pluralism.

18 See for instance, de Sousa Santos, "Law: A Map of Misreading. Toward a Postmodern Conception of Law" (1987) 14(3) J.L. \& Soc'y 279; de Sousa Santos, Toward a New Legal Common Sense (2 ${ }^{\text {nd }}$ ed.,2002), [hereinafter Santos, Legal Common Sense].

19 Darian-Smith, "Power in Paradise: The Political Implications of Santos's Utopia" (1998) 23 L. \& Soc. Inquiry 81 at 92. See also Santos' reply, de Sousa Santos, 
While perhaps true for the time (1992), Teubner's claim that “[p]ostmodern jurists love legal pluralism" 20 does not reflect the trends of the later 1990s, when the immanent critique of postmodernism rarely came into contact with either empirical or theoretical forms of pluralism. ${ }^{21}$ Nevertheless, this lack of interest on the part of critical scholars in the empirical dimensions of pluralism is perhaps countered by the attractiveness of some of its underlying political and ethical promises. These include pluralism's general challenge to the concept of state law, the 'critical pluralist' critique of the concept of law as a closed self-defining system, and the recognition of legal multiplicities which may be of strategic significance to the indigenous nations of colonial states.

\section{Legal Theory and the Resistance to Pluralism}

Despite the division between socio-legal studies and the more thought-based approaches to law, there are positive signs that the boundary between philosophical and sociological approaches is more permeable than it once was. Scholars such as Lacey, Cotterrell, Norrie and Tamanaha are actively attempting to dismantle this boundary. From the position of legal theory, however, there are several other points of resistance to legal pluralism beyond the disciplinary divide. For a start, legal pluralism decentres positive state-based law, regarding it only as a hierarchically superior system among various forms of law, or even downgrading its status so that it is only one among many laws, and possibly not even the most significant. ${ }^{22}$ In either case, pluralism is based on the perception that the category 'law' contains more than the law of a state. For those with a commitment to the law-state monad this apparent degradation of institutional law may involve a category mistake (misunderstanding the real limits of law), a serious threat to liberal political structures, or simply a confusing and unwarranted extension of the terminology of law to non-legal spheres of control. Perhaps most importantly, the idea of a limited law - where the distinction between law and non-law is clear and defensible - remains of importance to many legal theorists. ${ }^{23}$

There is also an issue of epistemological positioning to consider. While some pluralist scholarship has focused upon the interconnections between normative orders, ${ }^{24}$ it has also generally situated itself outside state-derived law. In contrast, as I have indicated, legal theory normally takes the

"Oppositional Postmodernism and Globalizations" (1998) 23 L. \& Soc. Inquiry 121 and comments by Gunther Teubner in, Teubner, "The Two Faces of Janus: Rethinking Legal Pluralism” (1992) 13 Cardozo L.Rev. 1443 at 1443-44.

20 Teubner, ibid.

21 An exception is Manderson, supra n.2.

22 Santos, Legal Common Sense, supra n.18, at, 94-95.

23 Schauer, "The Limited Domain of the Law" (2004) 90 Va.L.Rev. 1909. Austin, The Province of Jurisprudence Determined (1832/1954). See also critical comments by Douzinas, Warrington, and McVeigh, Postmodern Jurisprudence: The Law of Text in the Texts of Law (1991), p.25.

${ }^{24}$ See for instance, Teubner, "'Global Bukowina': Legal Pluralism in the World Society," in Teubner (ed.), Global Law Without A State (1997); Teubner, supra n.19. 
standpoint of the specialist insider - the lawyer, judge, or legal official ${ }^{25}$ - as central to knowledge about law. To the extent that the inside/outside distinction has practical force in understanding law, legal pluralism and legal philosophy need not even come into conflict as the former describes a situation of legal multiplicity in a social field whereas the latter takes just one of the existent forms of normativity and undertakes an analysis from the inside. Of course, there are real points of tension between legal pluralism and legal philosophy, for instance over the issue of when and how it is coherent to speak of more than one legal system within a geo-political terrain. ${ }^{26}$ The legal philosophical identification of law with state law does not necessarily preclude examination of non-legal forms of normativity, though legal philosophy does generally attempt to reserve the use of the term 'law' to state-derived law. Insofar as legal pluralists have insisted that law can be identified in non-state arenas, their claim is directly at odds with the positivist view of law as essentially associated with state mechanisms.

Finally, legal theory has often assumed that one of its core functions is to analyse the concept and identity of law, notions which seem to be intrinsically monistic and exclusive. Rather than accept the coexistence of incommensurable forms or views of law, legal theory has emphasised coherence, comparativeness and hierarchical ordering. As Desmond Manderson has suggested, this is arguably the symptom of an aesthetic resistance to legal pluralism on the part of orthodox legal philosophical discourse. ${ }^{27}$ The modernist inclination towards theoretical order, systematicity and coherence does not necessarily lead to a better 'truth', but is rather an aesthetic preference for totality and unity rather than disorder, contradiction and partial explanations. In its acceptance of a modernist paradigm of philosophical order, traditional legal theory is perhaps archetypally anti-pluralist: it is certainly set against William James' empirical pluralism, which he characterised as a 'turbid, muddy, gothic sort of an affair, without a sweeping outline and with little pictorial nobility' ${ }^{28}$

\section{Clearing the Ground}

If legal theory is to become more receptive to pluralism these several points of resistance need to be opened up for re-examination within legal theory, and not just within the excluded discourse of legal pluralism. Is state law necessarily the single expression of the 'legal' in any society? Is the knowledge of positive law held by the legal official or expert epistemologically superior to the knowledge held by others? ${ }^{29}$ (In any event, isn't expert knowledge also plural?) Philosophically, can positive law be reduced to a concept and an identity, or is it better understood as a plurality of concepts and a non-identity?

25 Consider, for instance, the role of legal officials in Hart, supra n.12; or the omniscient judge Hercules in Dworkin, supra n.13.

26 Roberts, "After Government? On Representing Law Without the State" (2005) 68(1) MLR 1.

27 Manderson, supra n.2.

28 James, A Pluralistic Universe (1977, first published 1909), p.26; see also Davies, "The Ethos of Pluralism" (2005) 27(1) Syd L.R. 88 at 98-100.

29 See, Kleinhans and Macdonald, supra n.2, at 40. 
Critical legal pluralists have offered some tantalising hints about the nature of a pluralist pluralism, but so far this research direction is relatively undeveloped. Taking my lead from the critical pluralist theory of the midlate $1990 \mathrm{~s},{ }^{30}$ in this and the next section I would like to offer a few provisional ideas about what a critical pluralist approach might have to offer to legal theory.

To begin with, in this section I need to articulate several presuppositions and theoretical qualifications.

First, the dangers of an undifferentiated or endless pluralism which fails to take account of the social discourses of power are all too evident. ${ }^{31}$ It would be naïve to suggest that pluralism per se is an ethical good: we need to maintain the space and the capacity for critique of oppressive practices whether they are undertaken under the auspices of a pluralist or a totalising political philosophy. Pluralism should not be seen as a recipe for endless relativism, but rather as a technique for disrupting the fixity of dominant distributions of power. I do not examine here the need for such a disruption of the singular positivist concept of law: that task has been undertaken by numerous other scholars in several theoretical contexts. ${ }^{32}$ Moreover, while I am assuming that there can be positive ethico-political consequences which would flow from a more open, heterogeneous understanding of law, this assumption is surely contextual since theories underdetermine political and ethical consequences. In other words, while a legal theory may certainly guide or influence one's ethical positioning, it would be wrong to suggest that it can fully determine a more just or egalitarian society. ${ }^{33}$

Second, insofar as my primary interest and expertise lies in legal theory or (as I have explained above) the immanent critique of positive law, the pluralist approach I am proposing here starts - perhaps paradoxically - as a pluralism of state-based law. In other words, the position is one of the inherent pluralism of positive law. In this sense, not only do I reject John Griffith's claim that pluralism "is an attribute of a social field and not of law," 34 I also bracket - momentarily at least - critique of the law-non-law distinction. In other words, in order to focus upon positive law, I take as given something which I believe to be patently false - the thesis of the limits of law. Importantly, however, I do not take it as a factual or real given: rather, what I take as given is the conventional discourse of the limits of law which does, of course, have an operational impact on the practice of law. This is not to say that the law is factually or even conceptually closed - it simply operates upon a discursive fiction of closure. The other matter which is left to one side in this analysis is the plurality of concepts of law as described by Tamanaha. ${ }^{35}$ While this is a theoretical direction which I would

30 In particular the sources cited at supra n.2.

31 See generally, Cooper, supra n.5.

32 For a summary of the political obstacles posed by the positivist concept of law to an equalization of socio-legal power see Davies, supra n.28.

33 Koskenniemi, "'By Their Acts You Shall Know Them. . ' (And Not by Their Legal Theories)" (2004) 15(4) EJIL 839. See also Santos, Legal Common Sense, supra n. 18

34 Griffiths, supra n.7.

35 Tamanaha, supra n.2, at Chap.7. 
certainly endorse, my focus at present is the inbuilt pluralism within what legal theory often takes to be a singular concept of law.

Third, I am not proposing here a new theory of law but rather a reorientation of theoretical questions and an attentiveness to the ethical positioning of the theorist of pluralism. Rather than theory, the few rather loosely structured points which follow might better be regarded as a series of meta-theoretical suggestions concerning the direction of legal theory. In themselves, they are insufficiently developed to count as an extended theoretical intervention, though they do crystallise what I see as some major elements in the nascent critical pluralist thought. Rather than a 'theory' of pluralism, which suggests conceptual stasis, I would prefer to speak of the 'ethos' of pluralism ${ }^{36}-$ suggesting a mutable orientation towards theoretical diversity.

Finally, most of the points of departure for a pluralist pluralism presented here are drawn negatively, that is, as the counterpoint to (though not rejection of) the two dogmas of monism I mentioned at the beginning of the paper. The term 'counterpoint' is Wendy Brown's metaphor for the way in which two truths can be simultaneously affirmed for political purposes without contradiction, assimilation, or dialectical synthesis. ${ }^{37}$ Given the multi-layered foundations of legal discourse in tradition, culture, language and politics, it seems nonsensical to insist upon a view of law which tries to avoid the co-existence of opposites. In other words, a pluralist pluralism, in my view, replaces the logic of 'either/or' with a more inclusive logic of 'both/and'. This is more than the presentation of a descriptively thick analysis of law: the 'both/and' refers not only to empirical depth but also to the co-existence of conceptual incommensurables which cannot be resolved, sublated, or assimilated to a greater unity.

My contention is therefore not that legal monism is at this moment 'false' in some absolute sense, as it clearly still plays a significant role in the practical understanding of law. ${ }^{38}$ Legal monism and the associated language of lawstate unity have a strong discursive force, and are accepted as paradigms of law within legal culture: on one level, law is monistic because legal subjects assume it to be so, and act in accordance with this assumption. But while the discourse of singularity pervades legal thought and carries much influence in the thinking of what law is, it is also possible to see law - including the centralist concept of law itself - as composed of plural dimensions. It is

36 Davies, supra n.28.

37 Brown, "Gender in Counterpoint" (2003) 4 Fem. Theory 365 at 367: 'At once open-ended and tactical, counterpoint emanates from and promotes an antihegemonic sensibility and requires a modest and carefully styled embrace of multiplicity in which contrasting elements, featured simultaneously, do not simply war, harmonize, blend or compete but rather bring out the complexity that cannot emerge through a monolithic or single melody'.

38 The evaluation of a theory as true or false is itself a theory-dependent exercise. On the one hand, I would say that monism does not correspond to the 'facts' about law, whether these are the social 'facts' of how people interact with law, the 'facts' of legal institutions, or even the 'facts' of judicial decision-making. On the other hand, centralist theories have the self-fulfilling truth of any discursively powerful social theory - that subjects behave as if the prevailing concept is true, and in so doing give a certain shape to the evidence, though never determine it completely. 
possible to see law as being at once singular and plural, and not composed of any essence which would reduce it to singularity alone.

In this sense, to borrow a phrase from Jean-Luc Nancy, law has a 'singular plural being' - its being is both singular and plural. ${ }^{39}$ Or, to use the spatial metaphor deployed by Desmond Manderson, law can be seen to be something like a fractal - a line or border of infinite length and complexity contained within finite space. ${ }^{40}$ The monistic concept of law cannot simply be discarded as a falsity because it is the paradigm within which the practical reality of law is generally played out. Nonetheless, even the monistic doctrine is meaningless without the 'playing out' or the experiential performance of law, a dimension of law which inevitably leads to the thought of pluralism. Such characterisations of law replace the logic of 'either/or' (that law is either singular or plural, and that it is either finite or infinite) with a logic of 'both/and' (that law can and does encompass contradictions, including the contradictions between being at once coherent and incoherent, and being at once singular and plural). ${ }^{41}$

\section{Conditions of a Pluralist Pluralism in Legal Theory}

In summary, if legal theory is to enter into dialogue with legal pluralism, it must question a number of its theoretical foundations as follows:

- $\quad$ its aesthetic preference for coherence and theoretical integration;

- the notion that law can be understood as an identity and a concept;

- the idea that there is a single or essential understanding of law;

- the epistemic privilege of legal experts;

- the grounding of knowledge about law in a one-dimensional reading of social fact;

- the presumption that a theory of law is possible;

- the inside/outside distinction;

- the logic of either/or.

In this section of the paper I want briefly to elaborate on the notion of a 'singular plural' law emphasising what might be regarded as the formal dimensions of such an approach.

(a) What is Pluralism? 'Irreducible Outness'

Perhaps belatedly, it seems important to offer some sort of analytical definition of pluralism, in order to permit identification of minimal conditions for characterising a thing as plural rather than singular. My

39 Nancy, Being Singular Plural (2000), p.28. There are many other mutations of the 'singular plural' which are revealed in Nancy's text.

40 Manderson, supra n.2, at 1066-67.

41 See also Peter Fitzpatrick's analysis of the concurrent determinateness of law and its responsiveness; Fitzpatrick, "Law in the Antinomy of Time: A Miscellany," p.97, in Ost and Van Hoecke (eds.), Temps et droit. Le Droit a-t-il pour vocation de durer? / Time and Law. Is it the Nature of Law to Last? (1998). 
working notion of pluralism is that it describes a situation in which incommensurable terms coexist in a comparative space. The definition is far from perfect, but it attempts to grasp the fact that pluralism generally refers to two or more theoretical objects (persons, legal systems, values, cultures) which come into contact with each other conceptually or physically, and which cannot be reduced to a singular form. So, for instance, while it would be possible to say that pluralism characterises the relationship between quantum physics and Western systems of musical notation, this is not a very theoretically interesting pluralism because the two exist in different spaces and rarely (one would imagine) come into theoretical contact. They do not co-exist, except in a rather trivial sense. In contrast, to use an example from Santos, the discipline of medicine might be said to consist of a plurality of different techniques and traditions $s^{42}$ - in relation to a particular ailment there might be several possible treatments, but these cannot be reduced to a singular form, even though a 'politics of definition' works to centralise one tradition and exclude others.

As defined by William James, pluralism is the position that there are things which are irreducible, external or totally 'other';

"Things are 'with' one another in many ways, but nothing includes everything, or dominates over everything. The word 'and' trails along after every sentence. Something always escapes. 'Ever not quite' has to be said of the best attempts made anywhere in the universe at attaining all-inclusiveness" 43

And;

"The irreducible outness of anything, however infinitesimal, from anything else, in any respect, would be enough, if it were solidly established, to ruin the monistic doctrine" 44

For James, pluralism was fundamentally opposed to rationalism and idealism - approaches which, he argued, carved singular and discontinuous concepts out of the complex and continuous 'perceptual flux'.

Although there are other definitions of pluralism, James' 'irreducible outness' provides a simple explanation which I wish to take as the benchmark of pluralism, with the added criterion that things which are 'irreducibly out' must come into contention somehow for this to be of theoretical interest. A finite trail of 'ands' ( $x$ and $y$ and $z$ ) is only pluralistic in the rather banal sense that no one system of thought can capture all that is, and therefore we need recourse to other systems of thought. It ceases to be banal when there is irreducibility between different understandings of the 'same' object (as in Tamanaha's non-essentialist pluralism) or when there is a radical irreducibility within the system or concept itself, making the doctrine of monism a pragmatic fiction.

42 Santos, Legal Common Sense, supra n.18, at 91.

43 James, supra n.28, at 145.

44 William James, as cited in O'Shea, "Sources of Pluralism in William James," p.27, in Baghramian and Ingram (eds.), Pluralism: The Philosophy and Politics of Diversity (2000). 
In the tradition of legal pluralism, James' notion of 'irreducible outness' is perhaps best compared to John Griffith's useful distinction between 'weak' and 'strong' instances of legal pluralism. 'Weak' legal pluralism refers to a situation where a single grundnorm for all law is maintained and thus 'the legal order of the state exhausts the legal ordering of society' ${ }^{45}$ but where nonetheless certain arenas of customary law are recognised and administered. In such a scheme, the plurality of law is contained within the state unity, and hence the pluralism is 'weak'. In contrast, 'strong' legal pluralism refers to "the coexistence within a social group of legal orders which do not belong to a single "system." 46 To use James" terminology, in weak pluralism there is assimilation of the other into the unity, whereas in strong legal pluralism, the 'irreducible outness' of legal orders is maintained. It seems nonetheless evident to me that a society may be described factually as incorporating both weak and strong pluralism: for instance, in Australia selected parts of indigenous law are to some degree recognised and administered by the state - the state legal system therefore enshrines a form of weak pluralism. But this does not account for the totality of Indigenous law, which maintains its own existence, its own 'irreducible outness', regardless of its partial recognition by the Australian state. Hence, in the geopolitical terrain of Australia, strong legal pluralism still exists even though it is often sidelined by the ideological dominance of legal monism.

As I have said, I start with the inherent pluralism of state/positive law, a notion which has also been advocated by critical legal pluralism; ${ }^{47}$ yet Griffiths has made it clear that such pluralism is 'weak' and not really pluralism at all. I agree with Griffiths that the only conceptually interesting form of pluralism is what he has defined as 'strong' pluralism, and at the same time the claim is made that this concept can be applied to state law as well as to the coexistence of state and non-state law. From an empiricalpositivist perspective, the idea must seem bizarre, to say the least. However, critical pluralism is not a pluralism of positively identifiable objects but, like critical theory in general, theorises the interconnection between individual subjects, their cultural location and processes of knowledge production. ${ }^{48} \mathrm{~A}$ pluralism of the different parts of positive law which are nonetheless all validated by the one grundnorm or rule of recognition is certainly a weak pluralism in the sense explained by Griffiths. ${ }^{49}$ There is no 'irreducible

45 Griffiths, supra n.7, at 5.

46 Griffiths, ibid., at 8

47 Manderson; and, Kleinhans and Macdonald; supra n.2.

48 Horkheimer, "Traditional and Critical Theory," in O'Connell et al. (eds.), Critical Theory: Selected Essays (1968).

49 Hans Kelsen recognised as much when he said that the basic norm 'constitutes the unity of a multitude of law.' Kelsen, Pure Theory of Law (1967), p.193. See for instance the summary of the work of Hans Petter Graver in, Dalberg-Larsen, The Unity of Law: An Illusion? On Legal Pluralism in Theory and Practice (2000), pp.103-106. Drawing on Graver's work, Dahlberg-Larsen identifies five axes of what he terms 'pluralism in official law': the multilayered historical construction of law, the 'different decision-making centres', the pluralism of underlying values, pluralistic notions of 'rationality', and the distinctness of the different areas of law. While it is interesting to consider the factual pluralism which characterises any legal system, insofar as all of these dimensions of law could be accounted for by the one grundnorm, the situation described remains one of weak pluralism. 
outness' because in the end all of the parts are legitimated by the legal structure (assuming, momentarily as I say, that it has limits). However, the pluralist approach to positive law which I am invoking, and which I think is in keeping with the direction of critical legal pluralism - especially that elaborated by Kleinhans and MacDonald - is an epistemological and an ontological pluralism and not just a pluralism of different elements of the one structure. ${ }^{50}$ The point is, that positive law is not 'one structure' but is irreducibly other to itself, characterised by non-identity. Thus positive law is epistemologically plural, meaning that it is futile to try to reduce law to a single analysis: knowledge of the law is layered and multiple, not flat or singular. At the same time, it is an ontological pluralism because the fundamental principles of positive law which are the expression of its being - legitimacy, validity, limitedness - are also conceptually complex and irreducible.

\section{(b) Epistemological Pluralism}

'Irreducible outness' can therefore be said to characterise theoretical accounts of law in its common positivist sense - law 'properly so called' is susceptible to multiple conceptualisations. In other words, there are many critical and theoretical accounts of this law, each of which provide different insights into the nature of positive law but which cannot be consolidated into the one theory. Put simply, there is a plurality of frames of reference as well as a plurality of critical positions or discourses, according to which positive law may be understood. Only one of these 'perspectives' is the positivist theory of law itself (a self-fulfilling account which describes and reinscribes the actuality of positivism) which dominates the terrain of analytical jurisprudence.

To give just one of many possible examples, within its own terms, analytical jurisprudence is incapable of accounting for and responding to the ways in which various forms of social power reside in and are reinforced by legal structures, a critique advanced compellingly by feminist legal theorists and socio-legal scholars. This 'irreducible outness' of power to the rationalistanalytical approach to law is a consequence of its exclusionary acts of selfdefinition. For instance, the rationalist approach to law generally holds that the form and content of law are separable and that questions of power relate to content not form, which can accordingly be safely excluded from the analytical understanding of the politically neutral form of law. As Roger Cotterrell comments, '[ $\mathrm{t}$ ]raditional legal scholarship' sees power as 'external and opposed to law'. ${ }^{1}$ Feminist legal theory and socio-legal research, on the other hand, consistently refuse to disengage law from its social and political context, ${ }^{52}$ and therefore characterise this alleged neutrality as a sham - a mere justificatory cover up for the reproduction of systemic power. In consequence, positivist accounts of law are at odds with both feminist and socio-legal theory - irreducibly external in some fundamental respects - and

50 Mouffe, "Democracy and Pluralism: A Critique of the Rationalist Approach" (1995) 16 Cardozo L.Rev. 1533 at 1535.

51 Cotterrell, supra n.10.

52 Cotterrell, ibid. See generally, Conaghan, "Reassessing the Feminist Theoretical Project in Law" (2000) 27 J.L. \& Soc'y 351. 
will remain so. ${ }^{53}$ The one cannot incorporate the other. Again, this is not to suggest that there can be no dialogue between critical and analytical approaches. And I would emphatically reject the contention that this kind of theoretical pluralism reduces all theories to 'equal but different' approaches: while it is true that theoretical approaches explain phenomena differently, and each may have its own abstract merits and its own level of purchase in cultural terms, there are often significant political and pragmatic consequences attaching to the choice of critical voice or theoretical approach.

\section{(c) Ontological Pluralism}

'Irreducible outness' is also to be found in positivist conceptions of law even when understood on its own terms as a singular and coherent system of law. The singularity and coherence of law in both theory and in practice is merely the theoretical veneer of its multiplicity and incoherence. ${ }^{54}$ What does it mean to say that pluralism is inherent in the positivist concept and practice of law? Essentially, it means that the identity of law is actually based on plurality or irreducible outness. It means that despite the best efforts of legal philosophers to find a concept of law which is coherent, unified, and separate, law is inevitably and irreducibly plural. Chantal Mouffe has made the point in relation to radical democratic thought;

"For a radical and plural democracy ... . pluralism is not merely a fact, something that we must bear grudgingly or try to reduce, but rather an axiological principle, that is, something constitutive at the conceptual level. .." 55

Mouffe uses the phrases 'an axiological principle' and 'something constitutive at the conceptual level' to refer to the inherent pluralism of radical democracy. In other words, radical pluralism moves beyond description of social facts (cultural differences, plural systems of law, plural social subcultures and so forth) and situates the plural at the 'radical' level of the concept itself. Such a moment in the development of theory rejects the attempt to unify and systematise, and accepts that (as William James said) "something always escapes" and that the "word 'and' trails along after every sentence." It is not, as has sometimes been said, a pessimistic denial of the possibility of knowledge, but rather a plain recognition of the fact that attempts to systematise can only succeed by positively cutting off the 'and'. Putting the 'and' back into legal philosophy, especially where it joins incommensurable thoughts and constructions of law, is a central objective of a more inclusive jurisprudence.

53 See generally Lacey, "Feminist Perspectives on Ethical Positivism," in Campbell and Goldsworthy (eds.), Judicial Power, Democracy and Legal Positivism, (2000). Lacey concludes that Campbell's 'ethical positivism' (emphasising the ethical rationale for the positivist approach) may have some points of contact with feminist legal thought. However, because it maintains positivism's 'theoretical separatism' between the legal and the political, it cannot fully accommodate feminist concerns.

54 See Davies, Delimiting the Law: 'Postmodernism' and the Politics of Law (1996). See also, Davies, supra n.4.

55 Mouffe, supra n.50, at 1535; see also, Mouffe, "Political Liberalism, Neutrality and the Political" (1994) 7 Ratio Juris 314. Mouffe's argument for a conceptual pluralism is the stimulus for my argument in this article. 
A 'pluralist' argument - though not necessarily named as such - is frequently made in relation to the multiple possibilities for the interpretation of law: that law is composed of multiple and indeterminate meanings or potential meanings which positivist and monist ideas of law constantly repress and normalise. ${ }^{56}$ Conventions of interpretation among those legal readers with power to determine the law (judges, lawyers, legislators) ensure for the most part that the corpus of legal meanings remains relatively stable and predictable. Such conventions may include so-called 'legal' rules of interpretation such as the literal rule or the golden rule. They may include the general principles of legal reasoning which are so familiar to lawyers: the doctrine of ratio decidendi, the evaluation of relevance, judging similarity and difference. More importantly interpretation is constrained by broader, less definable constructions of legal culture - what it means to be a lawyer, what it means to apply the law, what legal reasoning consists of. In each case, interpretative constructions can never be wholly internal to (or defined by) positive law. Rather, they indicate the embeddedness of positive law in a pluralistic social environment. Law is constantly re-created within this environment: the plurality of potential legal meanings, combined with the inescapable social pluralism which is law's foundation, exists alongside the more conventional, and separated, image of positive law.

The 'singular plural' nature of law is therefore especially clear when we think about the ways in which legal meanings are constructed. A plurality of possible legal meanings is controlled by a tightly-defined conventional law, and this tension between the many and the one provides opportunities for alternative meanings to emerge. For instance, while the legal definition of 'marriage' as the union for life of one woman and one man has remained relatively stable for some time, it is nonetheless undermined by ambiguity, especially as to the appropriate definition of 'man' and 'woman'. ${ }^{57}$ At the present time, such ambiguities - coupled with changes in social presuppositions about marriage - are posing a challenge to conventional interpretations.

Another, more technical, method of illustrating the "irreducible outness" of law to itself (or its inherent pluralism, to use the terminology of this article) is the well-established analysis of the paradoxical, self-contradictory foundations of law. ${ }^{58}$ Problems with the foundations of law have been well known to legal philosophy and constitutional thought for a very long time; ${ }^{59}$

56 See, for instance, Goodrich, Reading the Law (1986), pp.220-221; Douzinas, Warrington and McVeigh, supra n.23. See also, Davies, "Authority, Meaning, Legitimacy," p.115, in Goldsworth and Campbell (eds.), Legal Interpretation in Democratic States (2002).

57 See, for instance, the Australian case In Re Kevin (Validity of Marriage of Transsexual) [2001] FamCA 1074 (12 October 2001).

58 See for instance, Derrida, supra n.14; Fitzpatrick, Modernism and the Grounds of Law (2001); Motha, "The Sovereign Event in a Nation's Law" (2002) 13 L. \& Crit. 311; for a detailed exposition of Derrida's argument in 'Force of Law' in the context of legal philosophy, see Davies, Derrida and Law, supra n.14.

59 Gunther Teubner makes the point that decades of deconstruction and other forms of critique of law have made virtually no difference to its operating presumptions. What is pushing change in this area are historical - economic and political conditions in an era of globalisation. See Teubner, "The King's Many Bodies: The Self-Deconstruction of Law's Hierarchy" (1997) 31 L. \& Soc'y Rev. 763 at 
the point of the recent critical interest in these matters has been to illustrate that paradox and self-contradiction are symptomatic of deep incoherence and irrationality in any 'concept' of law. Rather than a mere theoretical failure to solve a riddle, paradoxes of foundation express the dynamism, the irreducibility, and the non-systematic nature of law. According to these critiques, the ideational unity of law is only achieved by the force of definitional exclusion (original and ongoing) of everything defined as 'other' to law - including morality, politics, and social diversity. Thus the 'other' is in fact integral to the conceptualisation and definition of law. This is clearly not a question only about legal language, of the words from which law is composed, though that is obviously a significant issue. It is an issue for the very dimensions of law, of what it is and how it situates itself.

\section{Subject-driven Law}

The epistemological and ontological pluralism outlined above is also enshrined in the subject who is/constructs the law. Legal subjects know law in plural ways, and live it in plural ways. Thus one of the most prominent areas in which the language of plurality within law can be deployed is by reference to law's subjects or persons. ${ }^{60}$ In this final section of the article, I want to offer some preliminary thoughts on this matter.

It is now commonplace to observe that law and legal theory idealise a particular type of subject. This subject tends to erase both the manifold contexts within which legal subjectivity arises and 'actual'/'natural' subjects whose subjectivities transgress the limits of law and are framed by a variety of social discourses little acknowledged by formal law (such as those relating to gender, heterosexuality, race, culture, level and type of education, and class). ${ }^{61}$ Law and its idealised subject have for some centuries taken the form of an imperfect mirror image of each other. ${ }^{62}$ Just as a national legal system is seen to be bounded, powerful within a limited domain, authoritative, and representing an objective order of norms, so the legal subject is classically seen as a rational, autonomous, self-possessed agent with control over his life

768-69 and 770-71. 'Derrida Himself' (to use Teubner's tongue-in-cheek capitalisation), emphasises the role of reiteration in the formation of 'Truth' which is not revealed, but made (over time, and by repetition).

${ }^{60}$ In both ordinary and philosophical language, the 'subject' is not the same thing as the 'person'; 'subject' implies subjection to a system and names an entity which is constituted within a language and context, whereas 'person' generally denotes a more naturalistic biological entity - centrally, a human being. However, since in positivist legal language a 'person' is often regarded as technically a fiction or construct of law, I think it is fair to say that the two concepts are much closer in legal language than in ordinary language, though not necessarily identical. See Naffine, "Who are Law's Persons? From Cheshire Cats to Responsible Subjects" (2003) 66 MLR 346.

61 See, for instance, Watson, "Power of the Muldarbi, Road to Its Demise" (1998) 11 A Fem LJ 28; Brown, States of Injury: Power and Freedom in Late Modernity (1995), p.152; Thornton, "The Cartography of Public and Private," p.11, in Thornton (ed.), Public and Private (1995); Irigaray, This Sex Which Is Not One (C. Porter trans., 1985), pp.23-33; Kapur, “'AA Love Song to Our Mongrel Selves': Hybridity, Sexuality and the Law" (1999) 8 Soc. \& L.S. 353.

62 The classic example, of course, is Thomas Hobbes' Leviathan, an entity representing the unity of law and state in the image of a man. 
and context. ${ }^{63}$ The subject repeats in his or her own sphere the image of the sovereign law. Thus, the images of subject and system in the liberal positivist tradition are premised on an idealised, neutralised, sameness - while the content of the system and the social identity of the subject may vary, their basic characteristics are conceptualised in a highly stylised fashion.

Social and political theory has moved beyond the notion that human individuals can be reduced to a formal type. Not only are subjects differently located and differently constructed in culture, they are also internally fragmented - not entities but rather pluralities. If the (non-necessary) tradition of legal theory mirroring the subject in order to construct its image of law continues, it stands to reason that the idea of law must also be headed towards plurality rather than a singular identity. Of course, that is somewhat speculative, but there are other reasons for associating the plurality of subjects with the plurality of law. If we take seriously the socio-legal perspective that law is fully embedded in social discourse, should we not then ask how the subject (always plural) sees, experiences and creates law? This is not intended to promote a 'subjective' notion of law, but rather a notion which takes adequate regard of the fact that social subjects are plural and that law is created by interactions in social spaces. ${ }^{64}$

The concept of law as presently conceived by positivist legal theory is regarded as an objectifiable thing, a definition which can be applied to certain kinds of normative phenomena. The singularity of law is based on this presumption. However, at least since Eugen Ehrlich argued in favour of 'living law' in the early 20th century, it has been clear that law is fully social: law lives in the social sphere and is not just an institutionalised reflection or crystallisation of selected social forms. Law exists in the living relationships and contexts of everyday life. ${ }^{65}$ Ehrlich differentiated such 'living' law from official law. A more contemporary statement of this might be that law is performative - it is the net effect of collective readings, practices, discourses, and inter-subjective relationships which subsist in social practice as well as in the semi-controlled environment of formal law. ${ }^{66}$ In the late twentieth century, the multiple environments of culture, race, gender, occupation, class and religion which condition such relationships became highly visible to legal theorists and legal sociologists. If we look at law as a dialogue between subjects themselves constituted by plural and

63 Nedelsky, "Law, Boundaries, and the Bounded Self," in Post (ed.), Law and the Order of Culture, (1991). See also, Naffine, "The Body Bag," in Naffine and Owens (eds.), Sexing the Subject of Law (1997).

${ }^{64}$ Hannah Arendt pointed out that the tradition of political philosophy tended to erase the plurality of human existence. I think this is an important point also to be made in relation to legal theory. See, generally Arendt, The Human Condition (1958).

65 Ehrlich, Fundamental Principles of the Sociology of Law (Walter Moll trans., 1962); Ziegert, "A Note on Eugen Ehrlich and the Production of Legal Knowledge" (1998) 20 Syd LR 108. See also, Stone, Social Dimensions of Law and Justice (1966), Ch.9 ("The Dependence of Law").

66 See e.g. Barthes "The Death of the Author" in Barthes, Image, Music, Text (1984), pp.142-48, and 145-6. 
contradictory cultural messages ${ }^{67}$ then law also must be regarded as inherently, irreducibly plural.

In this vein Kleinhans and MacDonald argue that critical legal pluralism "twists traditional analyses of law and society inside out" because it "investigates how narrating subjects treat law." 68 Similarly, emphasising the repeated indeterminate interpretations and acts of symbolisation that constitute law, Desmond Manderson argues that:

"The human dimension of misreading is necessary to any genuine pluralism, for it rejects the reification of 'law', 'system', 'culture', or 'community', as a thing which can think or read. Law is not manufactured by a 'multiplicity of closed discourses' precisely because it is only realised through the actions of human beings who exist simultaneously in several discourses and who are, therefore, themselves plural" 69

In other words, rather than ask how a reified and singular 'law' sees subjects, we need to be able to see the plurality of socially-situated subjects and their relationships and tensions as the starting point for law.

Arguably, HLA Hart partially effected this move towards the (normatively constructed) subject's reading of law by thinking of the secondary rules of law, including the rule of recognition, as that held to be such by legal officials. $^{70}$ Hart's 'readers' of law were not members of the general community as this 'would involve putting into the heads of ordinary citizens an understanding of constitutional matters which they might not have'. Rather, according to Hart

"The officials of the system may be said to acknowledge explicitly such fundamental rules conferring legislative authority: the legislators do this when they make laws in accordance with the rules which empower them to do so: the courts when they identify, as laws to be applied by them, the laws made by those thus qualified, and the experts when they guide the ordinary citizens by reference to the laws so made" 71

It is unsurprising - since those in a position to 'recognise' law were those whose identities are the most closely defined by it - that Hart ultimately reinscribes an objectivist, and singular concept of law. Reflection of lawyer's law (rather than the multiplicity of ways in which the term 'law' is used) is predominant in The Concept of Law. As a result, the nexus between the image of law and the image of the rational subject of law (in this case the even more limited subject in the form of officials) remains unbroken by Hart's theory. Similarly, but on a larger scale, Dworkin's attempt to find a (partial) source of law in community values erases the plurality of persons

67 See, Lyotard, The Postmodern Condition: A Report on Knowledge (1984), p.15.

68 Kleinhans and Macdonald, supra n.2; Cotterrell, "A Legal Concept of Community" (1997) 12(2) Can.J.L. \& Soc. 75; Melissaris, supra n.2, at 75; Cover, "Nomos and Narrative" (1983) 97(4) Harv.L.Rev. 4.

69 Manderson, supra n.2, at 1064.

70 Hart, supra n.12, at 61.

71 Hart, ibid. 
and their communities in the name of a single identifiable entity, the ideal judge Hercules. ${ }^{72}$

Why limit law to whatever is regarded as law by such a circumscribed élite or an idealised judge? Why not think of it as the accumulated readings, interpretations, and practices of plural subjects in dialogue with each other in the context of established conventions and texts? There are at least two ways in which we are plural: first, subjects are plural in their own self-identity; and second, we are all irreducible to every other subject. ${ }^{73}$ There is an 'irreducible outness' between one subject and another in that no aggregative model of a subject will be satisfactory; it will merely be a reduction to the same of different embodied subjects who have commonalities but are in the end unique. If law is not different from the social 'context', but embedded in it as a materialisation of multiple socio-political interactions, it must also be characterised by this plurality or otherness between us all. The central point is not that each person has their own experience and idea of law, ${ }^{74}$ but rather that conceptions and practices of law circulate in multiple cultural and subcultural discourses. ${ }^{75}$

Certainly some conceptions, practices, or interpretations of law are more powerful and more uniformly crystallised and institutionalised than others: in Western societies, state law as defined by legal 'insiders' is the entity typically vested with the profile of law per se. ${ }^{76}$ The apparent separateness of this version of state law from alternative legal conceptions is, however, undermined by its social and inter-subjective origins. Both the status and the content of state law are reliant on cultural dynamics, and cannot exist prior to social engagement: the separation of state law from other forms of law is a construction of, and therefore secondary to, social relationships. Moreover, subjects as law-creating agents are not separately bounded by a single normative space but co-exist across spaces, and cross-fertilise their normative presumptions: even Hart's 'legal officials' recognising and constructing law are also the subjects of socially plural environments.

\section{Conclusion}

It is at this point that we see a convergence of the social and philosophical dimensions of the deconstruction of the inside/outside or law/non-law distinction. The meaning of law (like all meaning) is essentially a social and inter-subjective meaning. While not necessarily denying the social origins of the meaning of law, legal theory often erases the multiple social sites and the dynamic nature of the process of legal meaning-making. In my view, even an adequate description of law $^{77}$ needs an appreciation of both the plural preconditions for any singular account of law and the political nature of the

72 See, Dworkin, supra n.13.

73 See also, Lugones, "Playfulness, 'World'-Travelling, and Loving Perception" (1987) 2 Hypatia 3.

74 It is true that each person is uniquely situated in relation to law, but this does not lead to individual or 'purely subjective' conceptions of law (much less solipsism), as subjectively-held concepts are in part the product of shared social meanings.

75 For some illustrations, see Santos, Legal Common Sense, supra n 18.

76 See, Cover, supra n.68.

77 Assuming that description which does not presuppose normative choice possible. 


\section{Northern Ireland Legal Quarterly [Vol. 57, No. 4]}

'acts of definition' which determine monistic views of law (such as the idea that law should be identified with state institutions and state will). 'Horizontal' accounts of law do not necessarily supplant traditional vertical accounts, ${ }^{78}$ but they can arguably uncover the pluralities and possibilities inherent in existing notions of law. Such narratives move beyond the traditional legal philosophical distinction between 'is' and 'ought': they are at once descriptive and aspirational because they illustrate how the pluralistic 'non-legal' domain not only intrudes into, but is essential to the definition and the practices of conventionally defined law.

78 See, Lacey, supra n.15, at 158-62. 